\title{
Evaluating the Performance of HEC-HMS and SWAT Hydrological Models in Simulating the Rainfall-Runoff Process for Data Scarce Region of Ethiopian Rift Valley Lake Basin
}

\author{
Mohammedreshid A. Aliye ${ }^{1,2}$, Alemu 0. Aga ${ }^{2 *}$, Teshale Tadesse ${ }^{2}$, Petros Yohannes $^{2}$ \\ ${ }^{1}$ College of Engineering and Technology, Bule Hora University, Bule Hora, Oromia Region, Ethiopia \\ ${ }^{2}$ Hawasa Institute of Technology, Hawasa University, Hawasa, Ethiopia \\ Email: woratorbi@gmail.com, *alemu.osore@hu.edu.et, teshale2000@gmail.com,pyohannes39@gmail.com
}

How to cite this paper: Aliye, M.A., Aga, A.O., Tadesse, T. and Yohannes, P. (2020) Evaluating the Performance of HEC-HMS and Swat Hydrological Models in Simulating the Rainfall-Runoff Process for Data Scarce Region of Ethiopian Rift Valley Lake Basin. Open Journal of Modern Hydrology, 10, 105-122.

https://doi.org/10.4236/ojmh.2020.104007

Received: August 4, 2020

Accepted: October 25, 2020

Published: October 28, 2020

Copyright $\odot 2020$ by author(s) and Scientific Research Publishing Inc. This work is licensed under the Creative Commons Attribution International License (CC BY 4.0).

http://creativecommons.org/licenses/by/4.0/

\begin{abstract}
A number of physically-based and distributed watershed models have been developed to model the hydrology of the watershed. For a specific watershed, selecting the most suitable hydrological model is necessary to obtain good simulated results. In this study, two hydrologic models, Soil and Water Assessment Tool (SWAT) and Hydrological Engineering Centre-The Hydrologic Modeling System (HEC-HMS), were applied to predict streamflow in Katar River basin, Ethiopia. The performances of these two models were compared in order to select the right model for the study basin. Both models were calibrated and validated with stream flow data of 11 years (1990-2000) and 7 years (2001-2007) respectively. Nash-Sutcliffe Error (NSE) and Coefficient of Determination $\left(R^{2}\right)$ were used to evaluate efficiency of the models. The results of calibration and validation indicated that, for river basin Katar, both models could simulate fairly well the streamflow. SWAT gave the model performance with the $\mathrm{R}^{2}>0.78$ and NSE $>0.67$; and the HEC-HMS model provided the model performance with the $\mathrm{R}^{2}>0.87$ and NSE $>0.73$. Hence, the simulated streamflow given by the HEC-HMS model is more satisfactory than that provided by the SWAT model.
\end{abstract}

\section{Keywords}

HEC-HMS, SWAT, Katar River Basin, Peak Flow, Rainfall-Runoff Simulation

\section{Introduction}

Modeling of hydrological processes, like rainfall runoff, infiltration, evapotrans- 
piration and groundwater discharge are the most essential tasks to manage the water resources of the basin [1] [2] [3]. To do so, many computer based models have been developed to simulate the hydrologic processes and the hydrologic effects of different watershed management issues [4] [5]. Today, the watershed models are used to implement an alternative management strategy in the areas of water resources allocation, reservoir siltation, flood control, land use land cove changes and climate change impact assessments [6].

A number of physically-based and distributed watershed models have been developed to model the hydrology of the entire watershed [7] [8]. For a specific watershed, selecting the most suitable hydrological model is necessary to obtain good simulated results and the success hydrologic prediction lies in the proper selection of model input parameters [1]. Such selection is highly challengeable for developing country due to shortage of studies that tested the applicability of the models. Recently, the most commonly used hydrological models are Hydrological Engineering Centre-Hydrologic Modeling System (HEC-HMS), Hydrological Simulation Program-Fortran (HSPF), Agricultural Non-Point Source (AGNPS), Soil and Water Assessment Tool (SWAT), and MIKE SHE [3] [5]. These models are developed for a specific area with the help of statistical observations based on parameters detected in the field [9]. Hence it may give fairly accurate results if they applied to conditions similar to those from which they were derived. But, as reported by Reference [10], models are applied in different regions where they were developed. For example SWAT is applied by Reference [11] in Warner Creek watershed, [12] in Big Creek watershed, [13] in Raccoon River watershed and [6] [14]-[19] in different basins of Ethiopia. Such a direct application of models in different regions where they were developed may be a bad practice.

In Wabash River watershed, USA, [20] were evaluated and compared SWAT and DWSM models. These results showed SWAT's weakness in predicting monthly peak flows (under estimating). Similarly, about eleven watershed-scale hydrological models were reviewed by Reference [21] and concluded that only HSPF, AnnAGNPS, MIKE-SHE, AGNPS, DWSM, SWAT and HEC-HMS were able to simulate all major watershed hydrological components. The result of these studies indicated that further investigation was needed to reach a solid conclusion about the superiority of one model over the others.

In China, Xixian River Basin, SWAT and Xinanjiang (XAJ) models were evaluated and compared by [22]. Their result indicated that as the both models have been performed well in the Xixian River Basin. For calibration and validation periods, both models have a PBIAS $<15 \%$, NSE $>0.69$ and $\mathrm{r}^{2}>0.72$. In Japan Ishigaki Island watershed, SWAT and GSSHA models were evaluated by [5] for high time resolution prediction of stream flow and sediment concentration. As the result, they have reported that, for long-term simulations, both models yielded the comparable results. In similar manner, the applicability of MIKESHE, APEX, SWAT models were tested by [2] in Canagagigue Watershed, Canada. And, as the result, they reported as the mean daily/monthly flow at the outlet of 
the Canagagigue Watershed simulated by MIKESHE was more accurate than that simulated by SWAT and APEX model, for both calibration and validation periods. In Virginia, Polecat Creek watershed, SWAT and HSPF were evaluated and reported as both models are able to simulate effectively the streamflow [23].

From these studies we can concluded that the models' performances are very site specific, and no one model is superior under all hydrologic conditions. Therefore, a complete understanding of comparative model performance requires applications under different hydrologic conditions and watershed scales. As reported by [6], SWAT has been successfully applied to simulate streamflow in different basins of the country Ethiopia and HEC-HEM has been also successfully applied for hydrological studies in different Ethiopian basins [14]. Therefore, the objective of the present study is to compare and assess the suitability of those two widely-used watershed simulation models, namely HEC-HMS and SWAT, for simulating the hydrology of a Katar River Basin, the Central Rift Valley (CRV) Lake Basin of Ethiopia.

\section{Materials and Methods}

\subsection{Description of Study Area}

The study area, Katar River Basin is sub catchment of Ethiopian CRV Basin. The Katar River and its tributaries start from the eastern parts of mountains Chilalo, Galema and Kakka of Arsi Zone and drains to Lake Ziway. Topographically, the Katar River Basin shows variation with altitude ranging from around $1617 \mathrm{~m}$ near Abura (at gauging Station) to about $4211 \mathrm{~m}$ above mean sea level on the high volcanic ridges along the eastern basin. Geographically, the basin lies between $7^{\circ} 21^{\prime} 34^{\prime \prime}$ to $8^{\circ} 9^{\prime} 55^{\prime \prime}$ North latitudes and $38^{\circ} 53^{\prime} 57^{\prime \prime}$ to $39^{\circ} 24^{\prime} 46^{\prime \prime}$ East longitudes and has a total surface area of $3354 \mathrm{~km}^{2}$ (Figure 1).

Regards to climate, the River basin is characterized by dry to sub-humid climate with mean annual precipitation of 650 to $1200 \mathrm{~mm}$ and temperature of the basin varies between $15^{\circ} \mathrm{C}$ and $25^{\circ} \mathrm{C}$ [24]. The rainfall pattern of the basin is largely influenced by the annual oscillation of the inter-tropical convergence zone. As the result [25] has classified the basin in three main seasons namely warm period (small rainy season) which extends from March to May, wet summers or longest rain season (Jun to September) and dry period (October-February). Within the basin, there are eight meteorological stations namely Assela, Arata, Kulumsa, Ketera Genet, Sagure, Bokoji, Ogolcho and Meraro.

Ethiopia-Ministry of Water Resources (MoWR) [26] has divided the geology of the basin into four rock units namely: age-Precambrian to Early Paleozoic crystalline basement succession rock, Mesozoic sedimentary rock, Oligocene to middle Miocene pre-rift volcanic rock and middle-Miocene to Holocene syn-and post-rift volcanic rock and unconsolidated sediments. Similarly, in the basin six most dominant soil types are identified by [26]. These are Andosols, Cambisols, Fluvisols Leptosols, Luvisols and Vertisol.

In the basin, there is dynamic land use change [26] [27] [28] and this has 


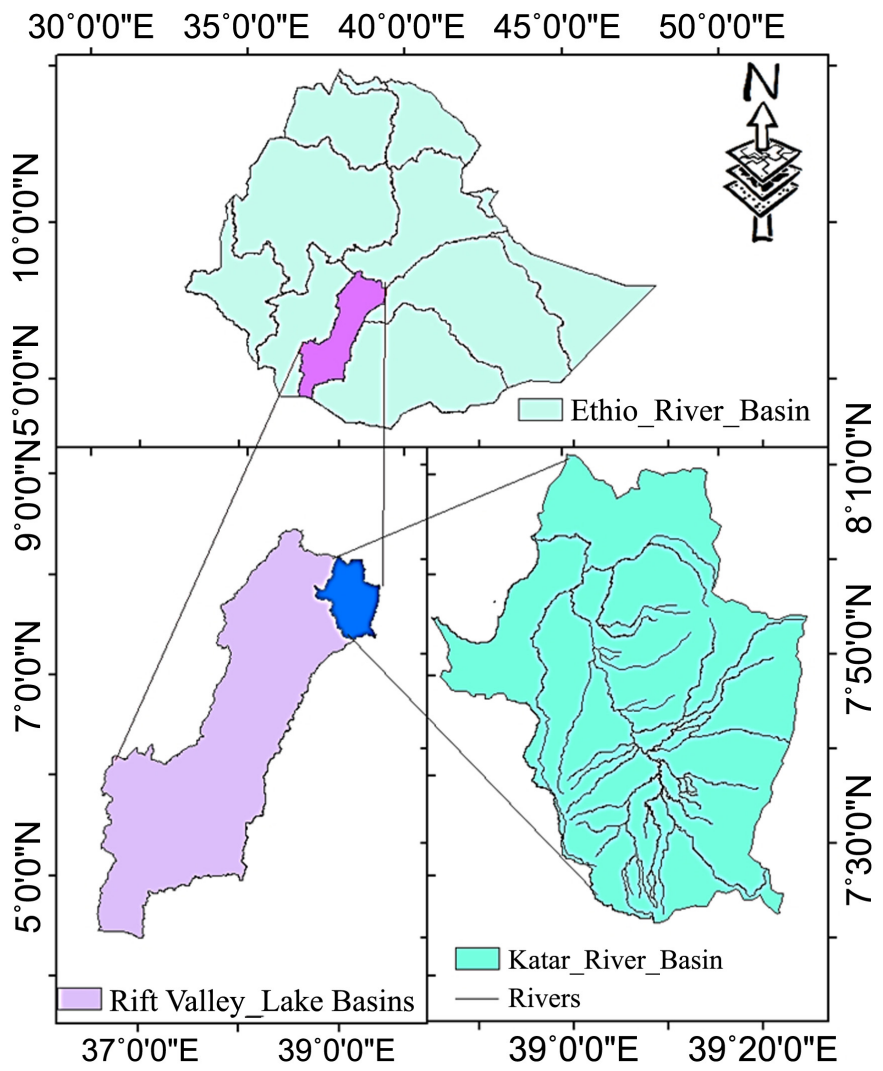

Figure 1. Location of Katar River Basin in the country Ethiopia.

extended to cultivate the marginal lands and for poor land management practices [26]. Inside the basin, land degradation, soil erosion and declining of soil fertility are seen due to cultivation of more marginal lands and improper land management systems [4] [26].

\subsection{Data Collection}

\subsubsection{Meteorological Data}

The meteorological data included daily precipitation, maximum and minimum temperature, daily wind speed, daily sunshine hours and daily relative humidity, and they were obtained from eight meteorological stations available within and nearby the study area. The collected data was appropriately adjusted for inconsistency, corrected for errors, extended for insufficient, and filled for missing. Daily data of 31 years (1987-2019) were collected for the study.

\subsubsection{Stream Flow}

For both SWAT and HEC-HMS models, discharge data were also required for calibration and validation of streamflow. On the Katar River Basin, Abura is the terminal gauging station and the runoff data of the station was collected from the Ethiopian Ministry of Water, Irrigation and Electricity.

\subsubsection{Soil Data}

In the year 2010, Ethiopian Rift Valley Lake Basin Master Plan study was con- 
ducted and, in that study, the soil samples were collected from all soil units of the basin. In Ethiopia Water Works Design and Supervision Enterprise soil analyses laboratory, all physical and chemical parameters of those soils were tested. Hence, from Ethiopia Ministry of Water Irrigation and Electricity (MoWIE), the analyzed soil laboratory results and the soil maps of the basin were collected. The soil properties required to set up the models namely soil texture, soil saturated hydraulic conductivity, grain size percentage, bulk density, texture class, soil available water and others were obtained from the analyzed laboratory results.

\subsubsection{DEM}

Digital elevation model is the basic input data for any hydrological modelling study, including SWAT and HEC-HMS. A $30 \mathrm{~m} \times 30 \mathrm{~m}$ digital elevation model (DEM) was obtained from shuttle radar topography mission (SRTM) of https://earthexplorer.usgs.gov/. From the collected DEM (Figure 2), the relevant basic information of the basin like physiographic characteristics of the catchment, including elevation and slope is extract in ArcGIS program.

\subsubsection{Land Use Land Cover}

To develop the SWAT and HEC-HMS model, one of the basic input data is land use cover map of the study area. For model calibration and validation, researchers are using a different years metrological and stream flow data with a fixed land use land cover map. Practically, the land use land cover pattern of the study

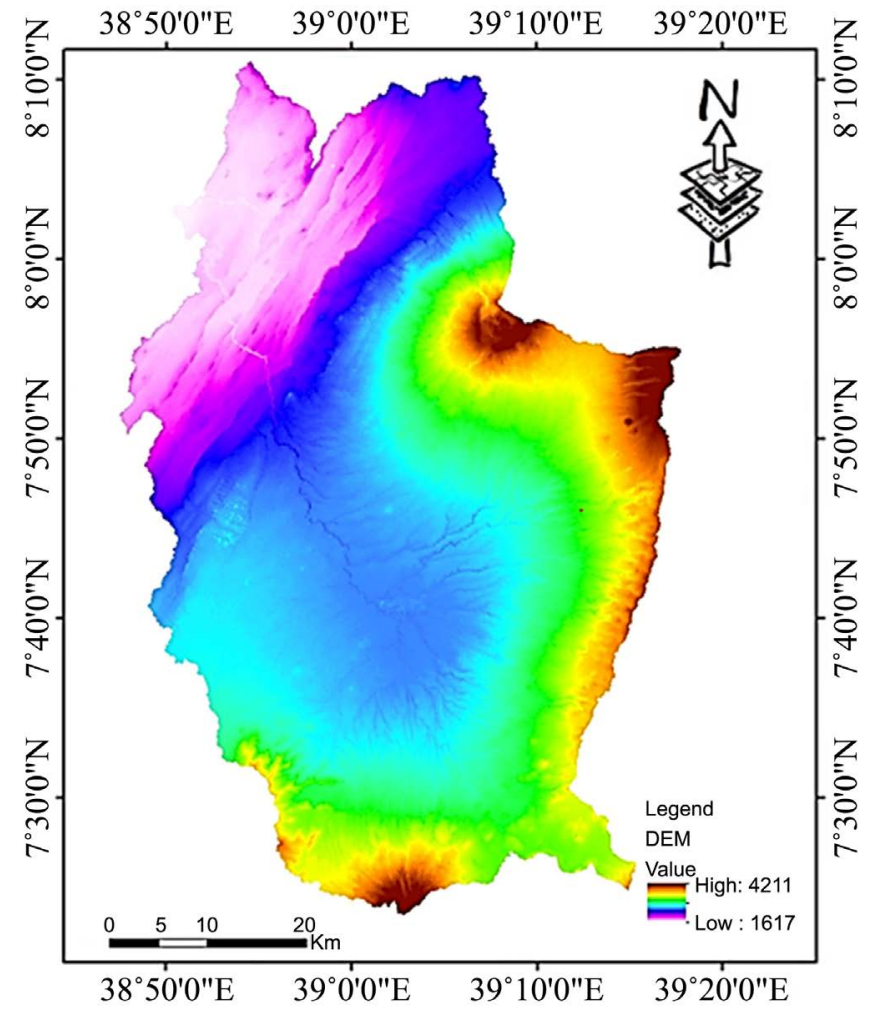

Figure 2. Digital elevation model (DEM) of study area. 
area will also changes with season. Unless we assume a constant land use type inside the study area, using a single land use map for model calibration and validation may be erroneous. In this study, the models are going to be calibrated and validated for the years 1990 to 2000 and 2001 to 2007 respectively. Hence the stream flow, metrological and Land use land cover data should be prepared for each calibration and validation periods. To do so, the land use land cover map of the study basin is prepared for the years 1990 and 2001 from Land sat images by downloading from United States Geological Survey website (https:earthexplorer.usgs.gov) (Figure 3).

The date from where the image was downloaded is given in Table 1 and they are cloud free and almost similar in months of the date.

The image is available in the form of GCS_WGS_1984 raster form with $30 \mathrm{~m}$ $\times 30 \mathrm{~m}$ resolutions. Preprocessing such as layer stacking, mosaic king and band color combination are carried out in order to Ortho-rectify the images. The images are process using GIS software. The developed land use and land cover image

Table 1. Characteristics of used satellite images.

\begin{tabular}{cccccc}
\hline Spacecraft ID & Path/row & Date & Pixel size & Band number & Senser-ID \\
\hline LANDSAT_5 & $168 / 54,55$ & $18 / 12 / 1990$ & $30 \times 30$ & 7 & ETM \\
\hline
\end{tabular}

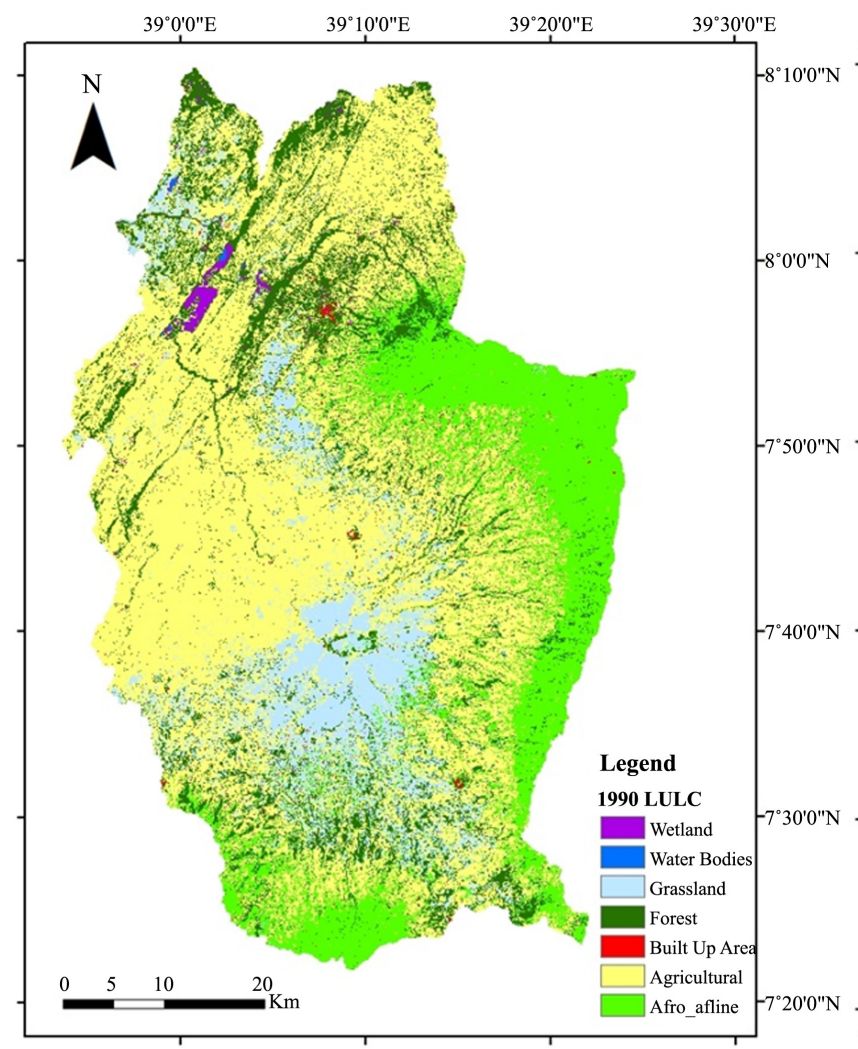

(A)

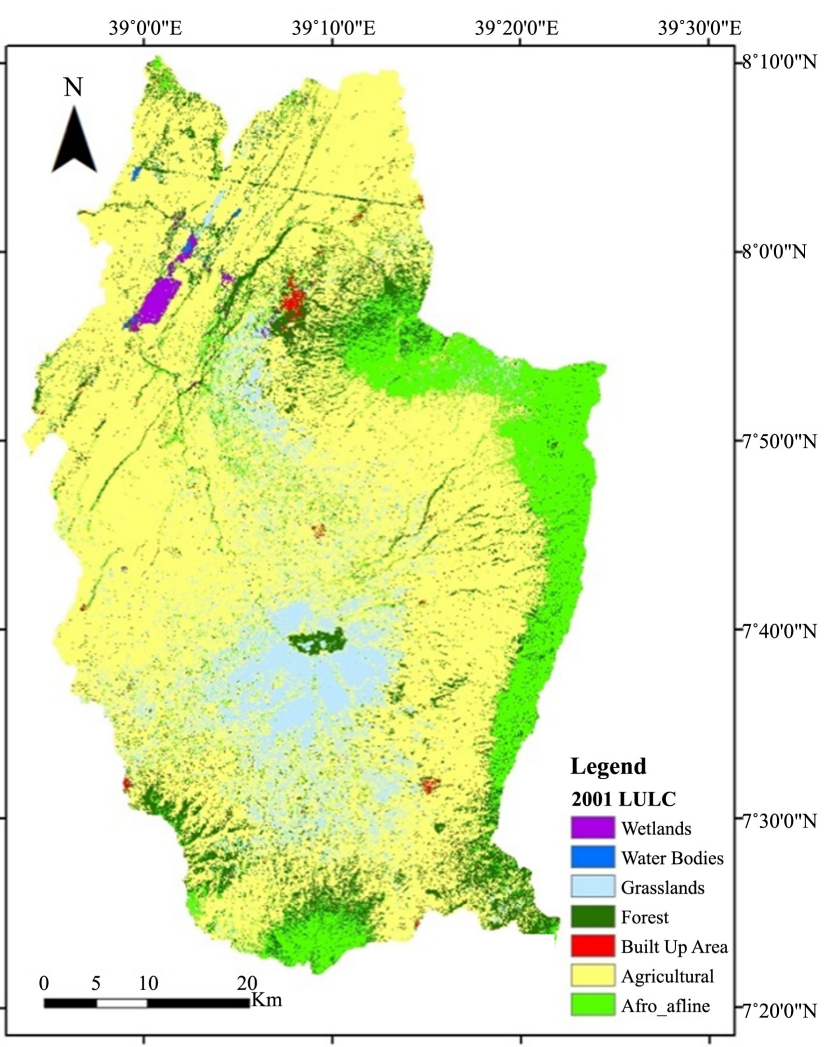

(B)

Figure 3. LULC map of the Katar River Basin. (A) For the years 1990 and (B) For the years 2001. 
was changed into Universal Transverse Mercator (UTM) projection by considering zone of the study area which is WGS-1984, UTM Zone 37N by using Arc GIS 10.2 software package.

For generated land used land cover (LULC) map of the study basin, the accuracy assessment was done by comparing the classification product with the reference data, which accurately reflects the true land cover. The accuracy assessment reflects the difference between the classified data and the referenced data. The most common way is to represent the classification accuracy of remotely sensed data Kappa coefficient [29]. The Kappa coefficient was calculated according to the formula given by [29]:

$$
K=\frac{N \sum_{i=1}^{r} x i i-\sum_{i=1}^{r}(x i+. x+i)}{N^{2}-\sum_{i=1}^{r}(x i+. x+i)}
$$

where " $r$ " is the number of rows in the matrix, $x i i$ is the number of observations in row $i$ and column $i, x i+$ and $x+i$ are the marginal totals of row $i$ and column $i$, respectively, and $N$ is the total number of observations.

After the critical evaluations given above, the exact study area's land use land cover was clipped from projected land use map. After reclassification, the classified land use raster map was converted to land use shape file maps using raster to polygon function. The developed land use land cover map was merged with soil data for curve number generation and extraction of area coverage for each class.

The LU/LC map of the study area was coded to the SWAT four letter codes and linked to the SWAT land use database. Hence, after preparing the look up table the land use types were made compatible with the input required by the model.

\subsection{SWAT Model}

The Soil and Water Assessment Tool (SWAT) is a physical based model used to estimate the runoff, sediment and chemical yields in gauged and un-gauged basins [30]. The hydrologic cycle of a basin simulated by SWAT is based on the following water balance equation:

$$
S W_{t}=S W_{0}+\sum_{i=1}^{t}\left(R_{\text {day }}-Q_{\text {surf }}-E_{a}-W_{\text {seep }}-Q_{g w}\right)
$$

where: $S W_{t}$ is final soil water content $(\mathrm{mm}), S W_{0}$ is initial soil water content $(\mathrm{mm})$,

$t$ is time (days), $R_{\text {day }}$ is amount of precipitation $(\mathrm{mm})$,

$Q_{\text {surf }}$ is amount of surface runoff $(\mathrm{mm})$,

$E_{a}$ is amount of evapotranspiration $(\mathrm{mm})$,

$W_{\text {seep }}$ is amount of water entering the vadose zone from the soil profile $(\mathrm{mm})$ and

$Q_{g w}$ is amount of return flow (mm).

In SWAT, the surface runoff from daily rainfall is estimated using a modified 
SCS curve number method, which estimates the amount of runoff based on local land use, soil type, and antecedent moisture conditions [31]. The surface runoff component of the water balance is determined from the SCS method as:

$$
Q_{\text {surf }}=\frac{\left(R_{\text {day }}-I_{a}\right)^{2}}{R_{\text {day }}-I_{a}+S}
$$

where, $I_{a}=0.2 \mathrm{~S}$ and $S=25.4(1000 / \mathrm{CN}-10)$; hence the amount of surface runoff is equated as:

$$
Q_{\text {surf }}=\frac{\left(R_{\text {day }}-0.2 S\right)^{2}}{R_{\text {day }}+0.8 S}
$$

where: $I$ is initial abstraction $(\mathrm{mm}), S$ is relation parameter $(\mathrm{mm})$ and $C N$ is curve number.

\subsubsection{Watershed Delineation}

Using the $30 \times 30 \mathrm{~m}$ resolution DEM data, the upstream of the gauging station Abura was delineated using ArcGIS 10.2 (Esri, Redlands, CA, USA). Accordingly, the entire study area has been divided into six sub-watersheds. After watershed delineation, land use, soil and slope characterization for watershed was performed using commands from the HRU analysis menu on the Arc SWAT Toolbar. The watershed was divided into hydrologic response units (HRU) which have a unique soil and land use combination. Based on the model setup with land use, soil and slope, and minimum area threshold values set as 5\%,10\% and 10\%, respectively, 69 Hydrological Response Units (HRU) were identified, which are unique combinations of land use, soil type and slope (Figure 4).

\subsubsection{Model Calibration and Validation}

To calibrate and validate the model, the daily stream flow data obtained from MoWIE were used. The model was run for the simulation period of 1 January 1999 through December 2007. The stream flow data of 11 years from 1990 to 2000 were used for calibration and the subsequent 7 years (2001-2007) were then used for validation period. In this study, the length of the time period used for calibration and validation were determined based on the existing observed data records. During calibration, sensitivity analyses were conducted automatically using the SUFI-2 program in SWATCUP software.

\subsection{HEC-HMS Mode}

HEC-HMS is hydrologic modeling software developed by the US Army Corps of Engineers- Hydrologic Engineering Center (HEC) and is designed to simulate the rainfall-runoff processes in a wide range of geographic areas such as large river basin water supply and flood hydrology to small urban and natural watershed runoff [14]. HEC-HMS model setup consists of a basin model, meteorological model, control specifications, and input data (time series data). Hence to prepare the input files for HEC-HMS, the DEM of the study area were processed 


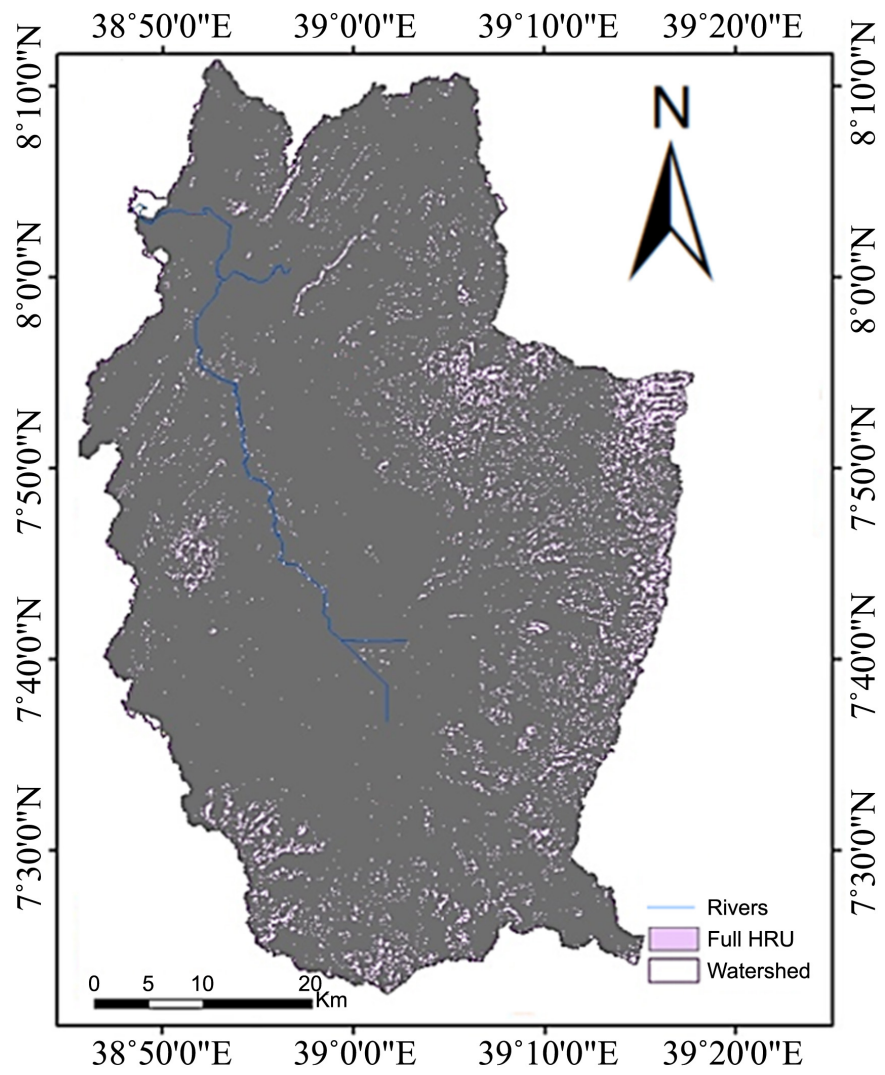

Figure 4. Hydrologic Response Unit of the study area.

using the geographic information system (GIS) interface of the HECGeoHMS model in an ArcGIS programme. Terrain pre-processing and basin processing tools were used to generate basin characteristic parameters and input files for HEC-HMS including a stream network, subbasin boundaries, and the connectivity of various hydrologic elements. The basin model and basin features which derived from HEC-GeoHMS were taken as a background map file and imported to HEC-HMS (Figure 5). In the meteorological model, the Priestley-Taylor evapotranspiration method was used for hydrological simulation and the sub basins areal precipitation was estimated by Thiessen polygon method with respect to the centroid point of each sub-basin.

The system encompasses runoff volume by computing the volume of water that is intercepted, evaporated, infiltrated, stored, and subtracting it from the total precipitation. In HEC-HMS model, around eleven kinds of loss estimation methods are embedded in the programme. In this study, Soil Curve Number (SCS Curve Number) method was used.

\subsection{Model Evaluation and Statistical Analyses}

The Nash-Sutcliffe efficiency (NSE) and coefficient of determination $\left(\mathrm{R}^{2}\right)$ were used as statistical indices to assess the model performance. $\mathrm{R}^{2}$ (the coefficient of determination) indicates the degree of linear relationship between simulated and observed data. A $\mathrm{R}^{2}$ value close to one indicates a better performance. However, 


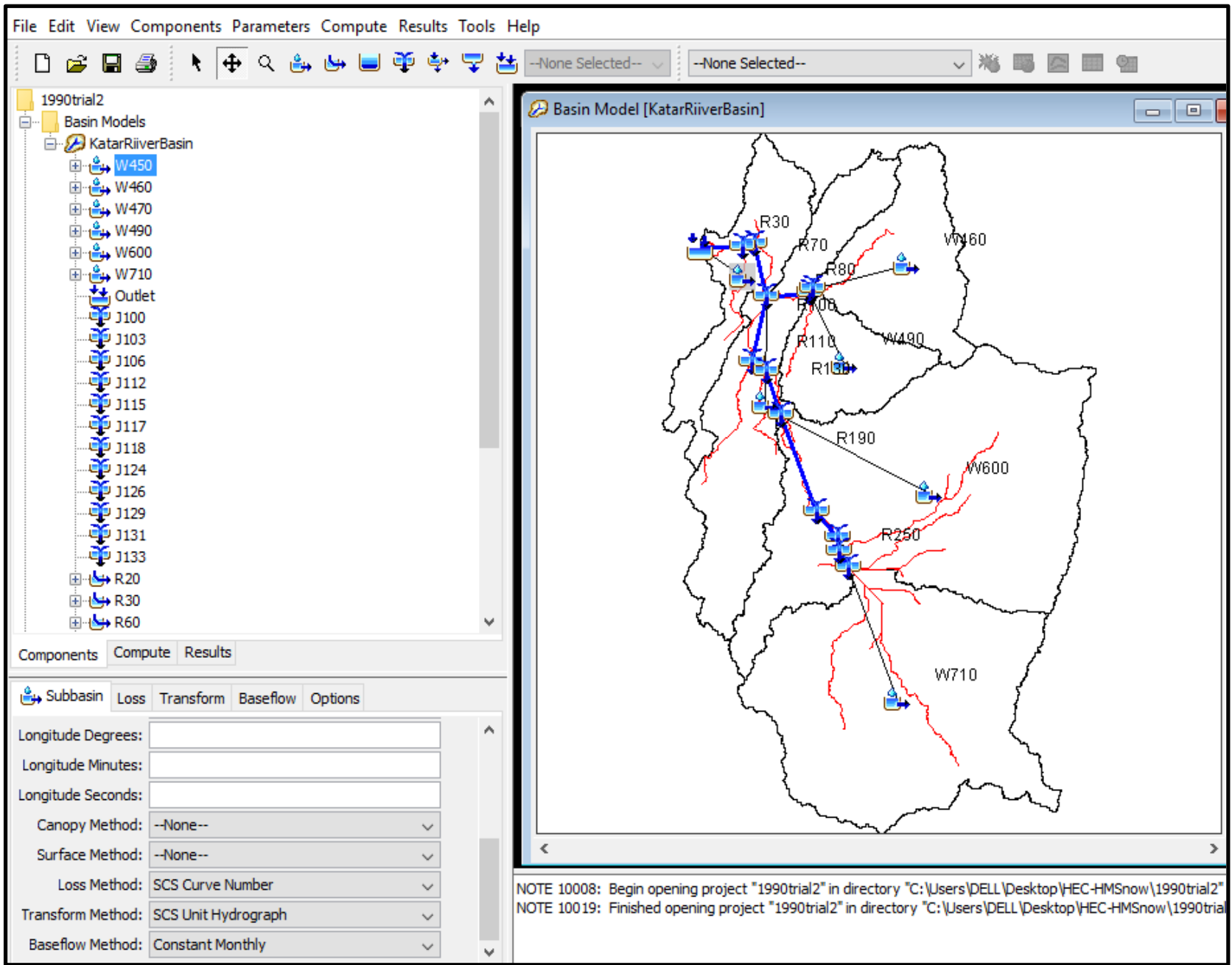

Figure 5. Back ground map file of Katar river basin.

it is very sensitive to extremely high values. The Nash-Sutcliffe efficiency (NSE) is one of the most commonly used criteria [32]. This is a normalized statistic, which can be used to determine the goodness of fit. The NSE ranges from $-\infty$ to 1 , with 1 indicating a perfect match [33].

\section{Results and Discussion}

\subsection{Sensitivity Analysis}

Out of the 16 parameters, only few parameters that are most sensitive for flows were determined based on $\mathrm{p}$-test and $\mathrm{t}$-stat. A t-stat determines the relative significance of each parameter and ranks the parameter based on the absolute values. To obtain optimal fitting with the measured data, calibration was conducted manually and automatically by SUFI-2 program. The most sensitive parameters identified during calibration are SCS runoff curve number (CN2.mgt), effective hydraulic conductivity in main channel (mm/hr) (CH_K2.rte), Saturated hydraulic conductivity ( $\mathrm{mm} / \mathrm{hr}$ ) (SOL_K.sol), Ground water "revap" coefficient (GW_REVAP.gw), available water capacity of the soil layer ( $\mathrm{mm} \mathrm{H}_{2} \mathrm{O} / \mathrm{mm}$ soil) 
(SOL_AWC.sol), surface runoff lag time (SURLAG.bsn), slope of watershed (HRU_SLP.hru), base flow alpha factor (days) (ALPHA_BF.gw) and groundwater delay (days) (GW_DELAY.gw). The sensitivity result shows the SCS runoff curve number (CN2.mgt) as a major critical parameter for SWAT model. For HEC-HMS model, SCS (unit hydrograph lag time, curve number, initial abstraction), Muskingum ( $\mathrm{k}$ and $\mathrm{x}$ ) and sub reaches as a major critica parameter with different sensitivity ranks (Table 2 ).

\subsection{HEC-HMS Model Simulation Result}

The calibration and validation of the HEC-HMS model for the Katar River Basin were carried out by comparing the simulated streamflow with the observed flow at main gauging station (Abura station).

The graphical representation of measured and simulated flows matched flows matched well for both calibration and validation periods (Figure 6 and Figure 7). This shows that the model produced a similar trend between observed and simulated streamflow during the calibration and validation periods. However, total runoff volume and peak flow were slightly overestimated. This difference might be due to the routing coefficients or simulating at an hourly time step. Based on the calibration and validation results, the model performance has been evaluated in terms of the statistical indicators (Table 3).

Table 2. Parameters sensitivity rank based on P-value, $\mathrm{t}$-stat and objective function.

\begin{tabular}{|c|c|c|c|c|c|}
\hline Parameter name & Description & $\begin{array}{l}\text { Min_ } \\
\text { value }\end{array}$ & $\begin{array}{l}\text { Max_ } \\
\text { value }\end{array}$ & $\begin{array}{l}\text { Fitted } \\
\text { value }\end{array}$ & Rank \\
\hline \multicolumn{6}{|c|}{ SWAT model } \\
\hline $\mathrm{CN} 2 . \mathrm{mgt}$ & Initial SCS CN II value & 35 & 98 & 58.9 & 1 \\
\hline SOL_K.sol & Saturated hydraulic conductivity & 0 & 2000 & 33.3 & 5 \\
\hline HRU_SLP.hru & Average slope steepness (\%) & 0 & 1 & 0.58 & 7 \\
\hline CH_K2.rte & Channel hydraulic conductivity & 0.01 & 500 & 286. & 6 \\
\hline GW_REVAP.gw & Ground water "revap" coefficient & 0 & 0.2 & 0.19 & 3 \\
\hline SOL_AWC.sol & Available water capacity & 0 & 1 & 0.61 & 8 \\
\hline SURLAG.bsn & Surface runoff lag time (days) & 0 & 1 & & 4 \\
\hline GW_DELAY.gw & Groundwater delay (days) & 0 & 500 & 401 & 2 \\
\hline ALPHA_BF.gw & Base flow alpha factor (days) & 0 & 1 & 0.15 & 9 \\
\hline \multicolumn{6}{|c|}{ HEC_HMS model } \\
\hline SCS.Lag (MI) & SCS unit hydrograph_lag time & 0.1 & 30,000 & * & 1 \\
\hline Curve number (AMC_II) & SCS curve number & 35 & 99 & * & 2 \\
\hline Initial abstraction (MI) & SCS Curve number_initial abstraction & 0.001 & 500 & * & 3 \\
\hline Muskingum_k(hr) & Flood wave travelling time & 0.001 & 150 & * & 4 \\
\hline Muskingum_x & Weighted coefficient of discharge & 0.001 & 0.5 & * & 5 \\
\hline Muskingum reaches & Muskingum sub reaches & 1 & 100 & * & 6 \\
\hline
\end{tabular}




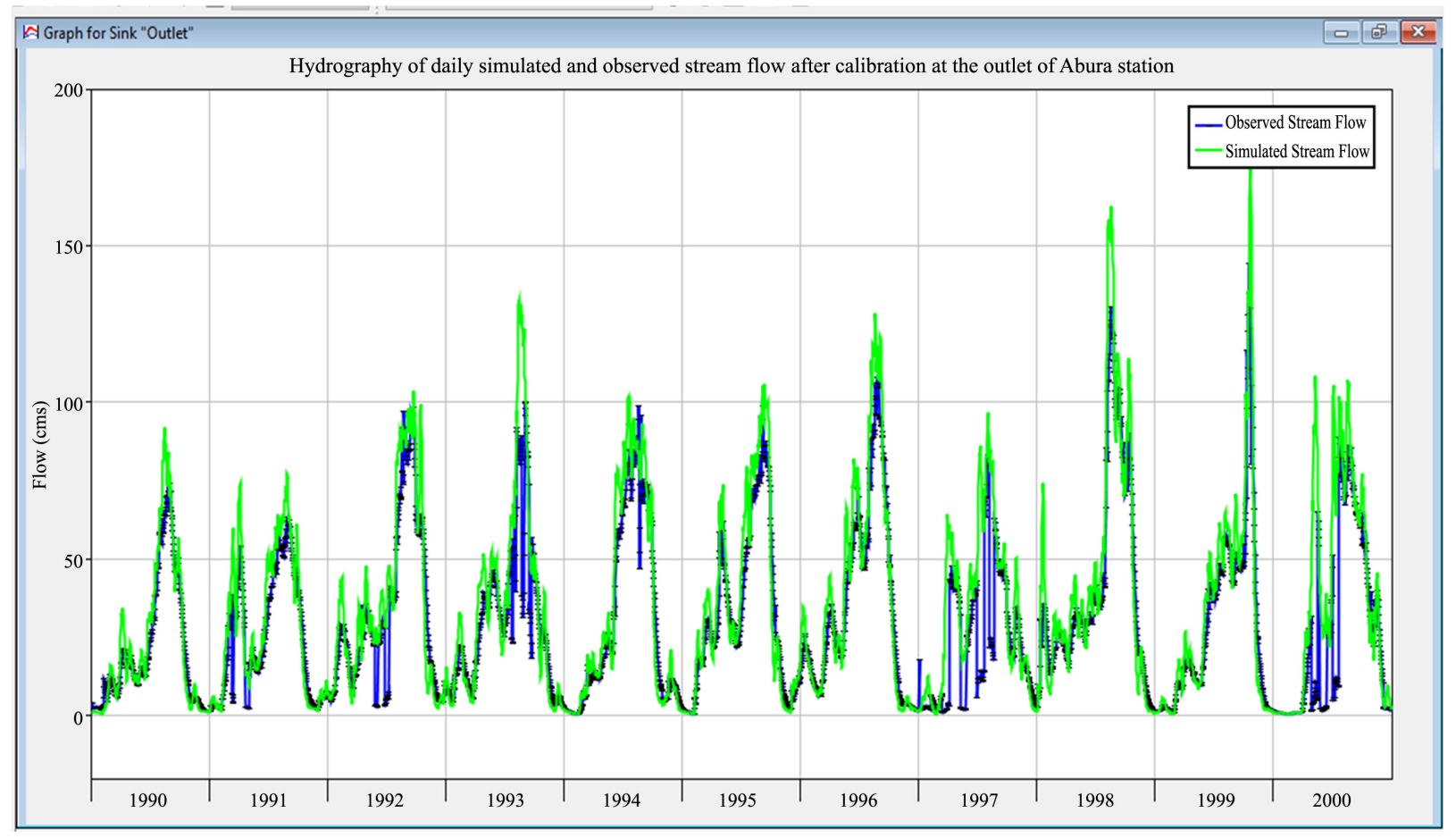

Figure 6. Simulated and observed stream flow after model calibration.

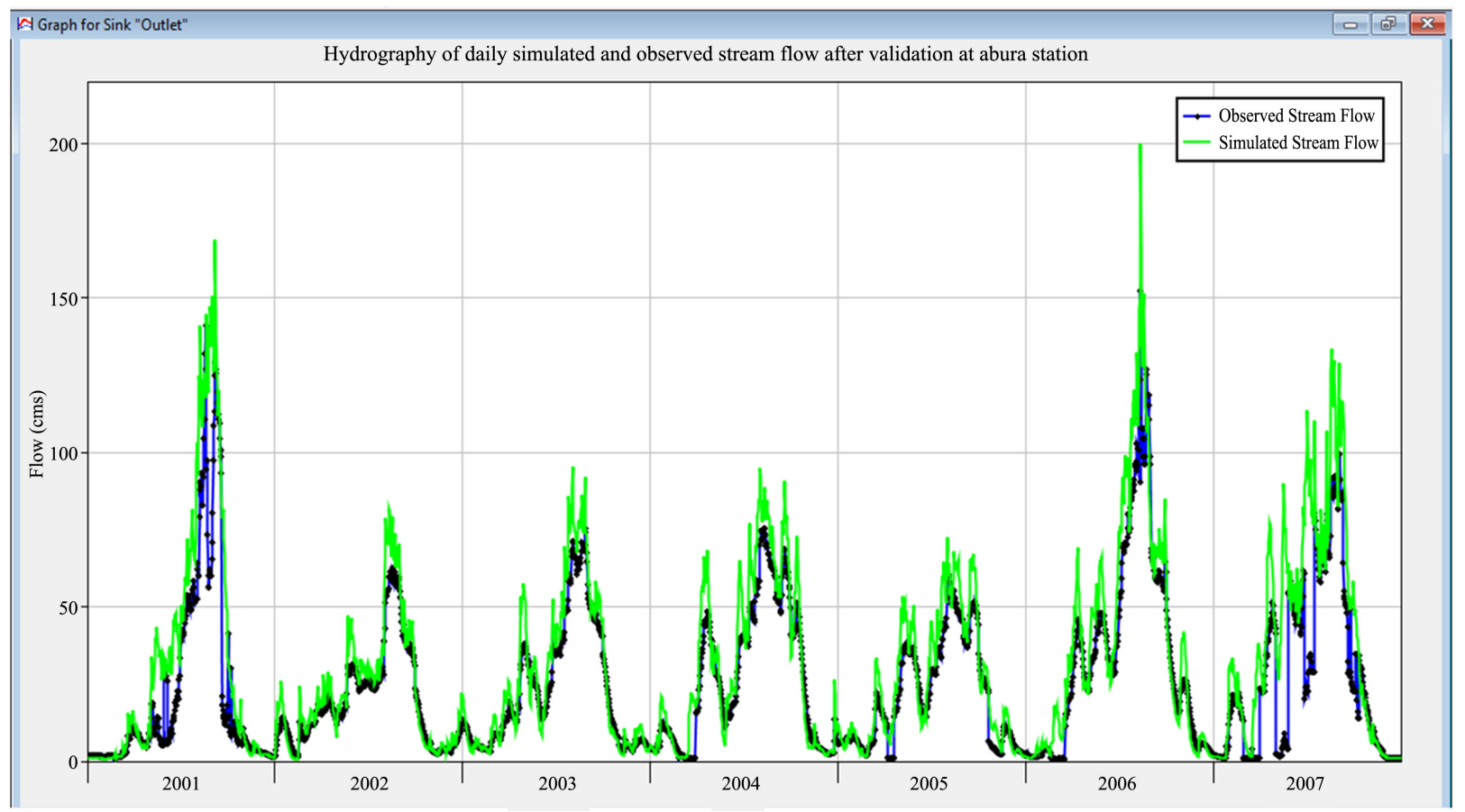

Figure 7. Simulated and observed stream flow after validation.

Table 3. Daily streamflow calibration and validation model performance statistics.

\begin{tabular}{cccc}
\hline Performance rating & Model & Calibration (1990-2000) & Validation (2001-2007) \\
\hline $\mathrm{R}^{2}$ & HEC-HMS & 0.88 & 0.87 \\
NSE & HEC-HMS & 0.75 & 0.73 \\
\hline
\end{tabular}


As recommended by [33], the high $\mathrm{R}^{2}$ and NSE values indicate the very good correlation and agreement between the observed and simulated values. Based with Reference [33] rated vales, the model performance statistics determined for the model HE-HMS (Table 3) is good to very good and hence the model HEC-HMS is a suitable model for hydrological related studies for the river basin Katar.

For full period (1990-2007), the simulated daily peak discharge at outlet of the study area is found to be $289.6 \mathrm{~m}^{3} / \mathrm{s}$ (Figure 8). For each sub-basin and rivers, the daily simulated discharge is estimated and based on the result, the higher runoff is generated from W600 and W710 sub-basins (See Figure 5), whereas, the minimum runoff is contributed by W450 sub-basin. The water depth increases as river reaches approaches to the outlet point.

Comparison of time-series of measured and simulated stream flow for full study years (1990-2007) at a common outlet station of Abura (Figure 8) shows that the shape and timings of the peak of observed and simulated stream flow graphs agree well for most of the study periods.

\subsection{SWAT Model Simulation Result}

The calibration and validation of the SWAT model for the Katar River basin were also conducted by comparing the simulated streamflow with the observed flow at the Abura gauging station. The plots of observed and simulated daily flow are shown in Figure 9 and Figure 10.

The calibration and validation greatly improved the agreement between the measured and simulated daily discharges. The graphical representation of observed and predicted monthly stream flows matched well for both calibration and validation periods (Figure 9 and Figure 10). The goodness-of-fit test statistics for calibration and validation periods are sown in Table 4. As shown in Table 4, all the numerical model performance indicators designated for the model performance evaluation are concordant with NSE and $\mathrm{R}^{2}$ values ranging 0.69 to 0.67 and 0.8 to 0.78 respectively, for the calibration and validation periods.

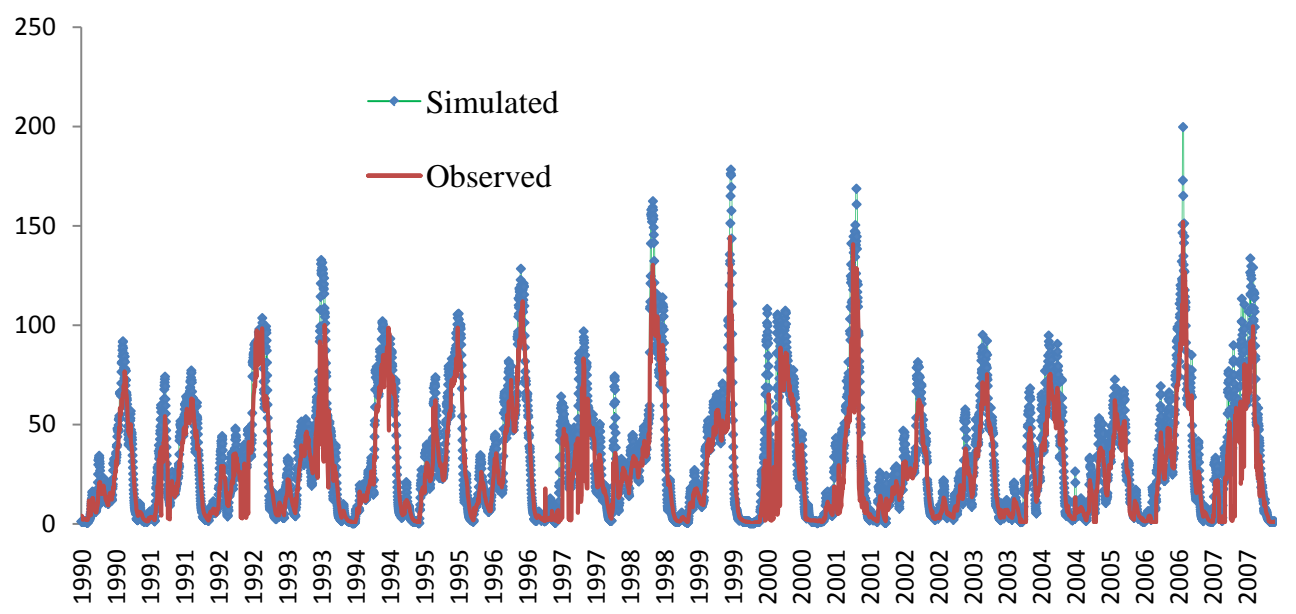

Figure 8. Simulated and observed stream flow for full period (1990-2007). 


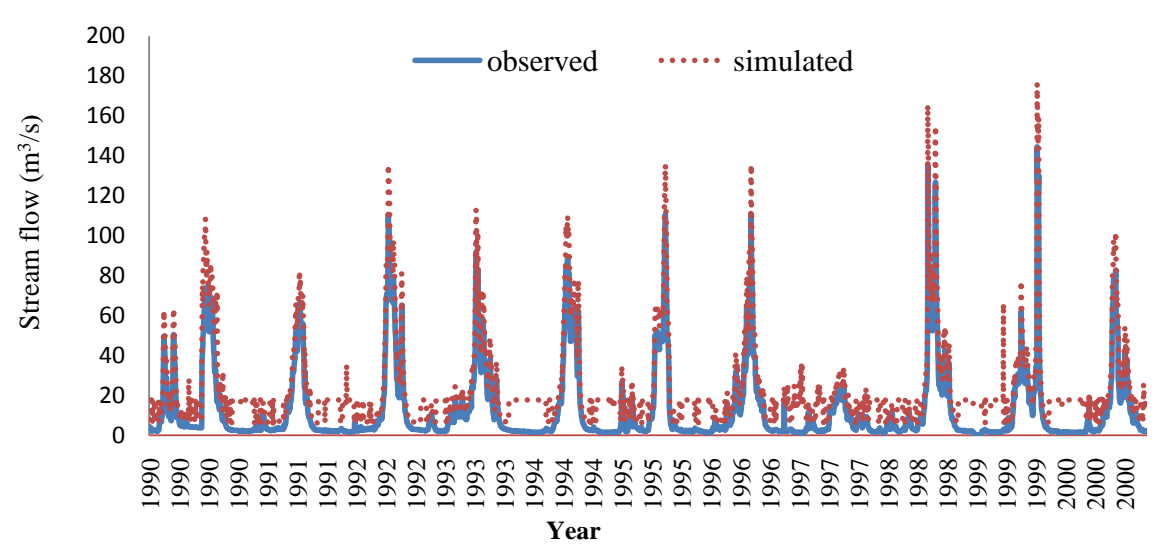

Figure 9. Daily stream flow at Abura gauging station by SWAT model after calibration.

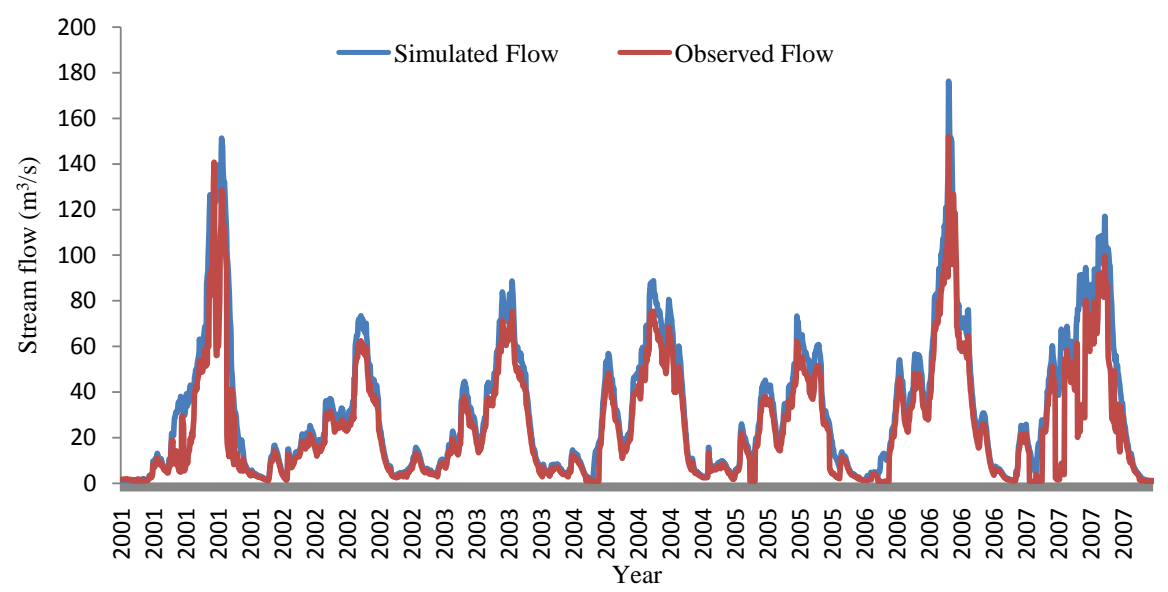

Figure 10. Daily stream flow at Abura gauging station by SWAT model after validation.

Table 4. Daily streamflow calibration and validation model performance statistics.

\begin{tabular}{cccc}
\hline Performance rating & Model & Calibration (1990-2000) & Validation (2001-2007) \\
\hline $\mathrm{R}^{2}$ & SWAT & 0.80 & 0.78 \\
$\mathrm{NSE}$ & SWAT & 0.69 & 0.67 \\
\hline
\end{tabular}

SWAT developers recommend an acceptable calibration for hydrology at a $\mathrm{R}^{2}>0.6$ and NSE $>0.5$ [34]. Similarly, its performance is good to very good compared with the statistical performance value recommended by Reference [33]. Based with numerical model performance measures, SWAT model had accurately simulated the measured stream flow. Therefore, similar to that of HEC-HMS model, SWAT is also a suitable model for the study area.

\subsection{Comparison of SWAT and HEC-HMS Models in Simulating the Rainfall-Runoff Process}

To compare the model performance in producing streamflow, experiments based on the well calibrated HEC-HMS and SWAT models were conducted. These results are shown for daily simulation period of the year 1990-2007 (Figures 6-10). The statistical indices (NSE and $\mathrm{R}^{2}$ ) are presented in Table 3 and 
Table 4. The results indicated that both models were generally able to simulate effectively the streamflow. However, HEC-HMS simulated hydrology of the basin more accurate than the SWAT model for both calibration and validation period. As shown in Table 3 and Table 4, HEC-HMS has the best NSE (0.75 and $0.73)$ and $\mathrm{R}^{2}(0.88$ and 0.87$)$ values when compared to those by the SWAT model (NSE values were 0.69 and 0.0 .67 and $\mathrm{R}^{2}$ values were 0.8 and 0.78 ) for Abura gauging station. In general, the results show that the HEC-HMS model is the most suitable model for hydrological modelling with high precision than SWAT. In similar manner, [2] were tested three Hydrological Distributed Watershed Models MIKE-SHE, APEX and SWAT at Grand River Basin, Canada. As the result, the simulated flows generated by the three models were quite similar and closely match the observed flow, for the calibration period. For validation, they reported as MIKE SHE predicted the streamflow slightly better than either SWAT or APEX. Reference [22] were also compared the performance of the SWAT and XAJ models, and showed that both models performed well in the Xixian River Basin, with a NSE $>0.69$ and $\mathrm{R}^{2}>0.72$ for both calibration and validation periods. SWAT and HEC-HMS model were compared for their applicability on Central Highlands of Vietnam by [3] and reported that as both models could simulate fairly well the streamflow for the study area.

\section{Conclusion}

This study evaluates the performances of two hydrologic models, namely, HEC-HMS and SWAT, to find the suitable model for hydrological modeling in Katar river basin, Ethiopia. The two models require almost the same data input and model parameters. Both models were calibrated using the observed daily streamflow at Abura gauging station for the period of 1990 to 2000 and validated for a period of 2001 to 2007. The results of calibration and validation indicated that, for River Basin Katar, both models could simulate fairly well the streamflow. SWAT gave the model performance with the $\mathrm{R}^{2}>0.78$ and NSE $>0.67$; and the HEC-HMS model provided the model performance with the $\mathrm{R}^{2}>0.87$ and NSE $>0.73$ for the calibration and validation periods. In general, the simulated streamflow given by the HEC-HMS model is more satisfactory than that provided by the SWAT model.

\section{Acknowledgements}

We would like to thank Ethiopian Ministry of Water, Irrigation, and Electricity and National Meteorological Service Agency for providing the necessary data.

\section{Conflicts of Interest}

No conflict of interest is declared by the authors.

\section{References}

[1] Bredesen, A. and Brown, C.J. (2019) Comparison of Hydrologic Model Perfor- 
mance Statistics Using Rain Gauge and NEXRAD Precipitation Input at Different Watershed Spatial Scales and Rainfall Return Frequencies for the Upper St. Johns River, Florida USA. Proceedings, 7, 11. https://doi.org/10.3390/ECWS-3-05806

[2] Golmohammadi, G., Prasher, S., Madani, A. and Rudra, R. (2014) Evaluating Three Hydrological Distributed Watershed Models: MIKE-SHE, APEX, SWAT. Hydrology, 1, 20-39. https://doi.org/10.3390/hydrology1010020

[3] Khoi, D.N. (2016) Comparision of the HEC-HMS and SWAT Hydrological Models in Simulating the Stream Flow. Journal of Science and Technology, 53, 189-195.

[4] Aga, A.O., Melesse, A.M. and Chane, B. (2020) An Alternative Empirical Model to Estimate Watershed Sediment Yield Based on Hydrology and Geomorphology of the Basin in Data-Scarce Rift Valley Lake Regions, Ethiopia. Geosciences, 10, 17. https://doi.org/10.3390/geosciences10010031

[5] Sith, R. and Nadaoka, K. (2017) Comparison of SWAT and GSSHA for High Time Resolution Prediction of Stream Flow and Sediment Concentration in a Small Agricultural Watershed. Hydrology, 4, 27. https://doi.org/10.3390/hydrology 4020027

[6] Aga, A.O., Chane, B. and Melesse, A.M. (2018) Soil Erosion Modelling and Risk Assessment in Data Scarce Rift Valley Lake Regions, Ethiopia. Water, 10, 1684. https://doi.org/10.3390/w10111684

[7] Aga, A.O., Melesse, A.M. and Chane, B. (2019) Estimating the Sediment Flux and Budget for a Data Limited Rift Valley Lake in Ethiopia. Hydrology, 6, 1. https://doi.org/10.3390/hydrology6010001

[8] Bobba, A.G., Singh, V.P. and Bengtsson, L. (2000) Application of Environmental Models to Different Hydrological Systems. Ecological Modelling, 125, 15-49. https://doi.org/10.1016/S0304-3800(99)00175-1

[9] Hajigholizadeh, M., Melesse, A. and Fuentes, H. (2018) Erosion and Sediment Transport Modelling in Shallow Waters: A Review on Approaches, Models and Applications. International Journal of Environmental Research and Public Health, 15, 518. https://doi.org/10.3390/ijerph15030518

[10] Steenhuis, S., Collick, S., Easton, M., Leggesse, S., Bayabil, K., White, E.D., Awulachew, S.B., Adgo, E. and Ahmed, A.A. (2009) Predicting Discharge and Sediment for the Abay (Blue Nile) with a Simple Model. Hydrological Processes, 23, 3728-3737. https://doi.org/10.1002/hyp.7513

[11] Chu, T.W., Shirmohammadi, A., Montas, H. and Sadeghi, A. (2004) Evaluation of the SWAT Model Sediment and Nutrient Components in the Piedmont Physiographic Region of Maryland. Transactions of the ASAE, 47, 1523-1538. https://doi.org/10.13031/2013.17632

[12] Muleta, M.K. and Nicklow, J.W. (2005) Decision Support for Watershed Management Using Evolutionary Algorithms. Journal of Water Resources Planning and Management, 131, 35-44. https://doi.org/10.1061/(ASCE)0733-9496(2005)131:1(35)

[13] Jha, M.K., Gassman, P.W. and Arnold, J.G. (2007) Water Quality Modeling for the Raccoon River Watershed Using SWAT. Transactions of the ASABE, 50, 479-493. https://doi.org/10.13031/2013.22660

[14] Demlie, G.Z. and Melesse, A.M. (2018) Applicability of a Spatially Semi-Distributed Hydrological Model for Watershed Scale Runoff Estimation in Northwest Ethiopia. Water, 10, 923. https://doi.org/10.3390/w10070923

[15] Dessu, S., Melesse, A.M., Bhat, M. and McClain, M.E. (2014) Assessment of Water Resources Availability and Demand in the Mara River Basin. Catena, 115, 104-114. https://doi.org/10.1016/j.catena.2013.11.017 
[16] Dessu, S. and Melesse, A.M. (2013) Impact and Uncertainties of Climate Change on the Hydrology of the Mara River Basin, Kenya/Tanzania. Hydrological Processes, 27, 2973-2986. https://doi.org/10.1002/hyp.9434

[17] Dessu, S. and Melesse, A.M. (2012) Modelling the Rainfall-Runoff Process of the Mara River Basin Using the Soil and Water Assessment Tool. Hydrological Processes, 26, 4038-4049. https://doi.org/10.1002/hyp.9205

[18] Setegn, S.G., Rayner, D., Melesse, A.M., Dargahi, B. and Srinivasan, R. (2014) Impact of Climate Change on the Hydroclimatology of Lake Tana Basin, Ethiopia. Water Resources Research, 47, W04511. https://doi.org/10.1029/2010WR009248

[19] Yesuf, H.M., Assen, M., Alamirew, T. and Melesse, A.M. (2015) Modeling of Sediment Yield in Maybar Gauged Watershed Using SWAT; Northeast Ethiopia. Catena, 127, 191-205. https://doi.org/10.1016/j.catena.2014.12.032

[20] Borah, D.K., Arnold, J.G., Bera, M., Krug, E.C. and Liang, X.Z. (2007) Storm Event and Continuous Hydrologic Modeling for Comprehensive and Efficient Watershed Simulations. Journal of Hydrologic Engineering, 12, 605-616. https://doi.org/10.1061/(ASCE)1084-0699(2007)12:6(605)

[21] Borah, D.K. and Bera, M. (2003) Watershed-Scale Hydrologic and Nonpoint-Source Pollution Models: Review of Mathematical Bases. Transactions of the ASAE, 46, 1553-1566. https://doi.org/10.13031/2013.15644

[22] Shi, P., Chen, C., Srinivasan, R., Zhang, X.S., Cai, T., Fang, X.Q., Qu, S.M., Chen, X. and Li, Q.F. (2011) Evaluating the SWAT Model for Hydrological Modeling in Xixian Watershed and Comparison with the XAJ Model. Journal of the American Water Resources Association, 25, 2595-2612. https://doi.org/10.1007/s11269-011-9828-8

[23] Im, S., Brannan, K., Mostaghimi, S. and Cho, J. (2003) A Comparison of SWAT and HSPF Models for Simulating Hydrologic and Water Quality Responses from an Urbanizing Watershed. Proceedings of 2003 ASAE Annual Meeting, Las Vegas, 27-30 July 2003.

[24] Aga, A.O. (2019) Modeling Sediment Yield, Transport and Deposition in the Data Scarce Region of Ethiopian Rift Valley Lake Basin. PhD Dissertation, Addis Ababa Institute of Technology, Addis Ababa.

[25] Legesse, D. (2002) Analysis of the Hydrological Response of the Ziway-Shala Lake Basin (Main Ethiopian Rift) to Changes in Climate and Human Activities.

[26] MOWR (The Federal Democratic Republic of Ethiopia-Ministry of Water Resources) (2010) Rift Valley Lakes Basin Integrated Resources Development Master Plan Study Project. Addis Ababa.

[27] Desta, H. and Fetene, A. (2020) Land-Use and Land-Cover Change in Lake Ziway Watershed of the Ethiopian Central Rift Valley Region and Its Environmental Impacts. Land Use Policy, 96, Article ID: 104682. https://doi.org/10.1016/j.landusepol.2020.104682

[28] Zeray, L., Roehrig, J. and Chekol, D.A. (2006) Climate Change Impact on Lake Ziway Watershed Water Availability, Ethiopia. Proceedings of the Conference on International Agricultural Research for Development, 18-23.

[29] Congalton, R. and Green, G. (1999) Assessing the Accuracy of Remote Sensed Data. Remote Sensing of Environment, 37, 35-46. https://doi.org/10.1016/0034-4257(91)90048-B

[30] Arnold, J. and Fohrer, N. (2005) SWAT2000: Current Capabilities and Research Opportunities in Applied Watershed Modelling. Hydrological Processes, 19, 563-572. 
https://doi.org/10.1002/hyp.5611

[31] Setegn, S.G., Melesse, A.M., Wang, X., Vicioso, F. and Nunez, F. (2010) Calibration and Validation of ArcSWAT Model for Prediction of Hydrological Water Balance of Rio Haina Basin, Dominica Republic. Volume VI, GIS \& Water Resources, Orlando.

[32] Nash, J.E. and Sutcliffe, J.V. (1970) River Flow Forecasting through Conceptual Models Part I-A Discussion of Principles. Journal of Hydrology, 10, 282-290. https://doi.org/10.1016/0022-1694(70)90255-6

[33] Moriasi, D.N., Arnold, J.G., Liew, M.W.V., Bingner, R.L., Harmel, R.D. and Veith, T.L. (2007) Model Evaluation Guidelines for Systematic Quantification of Accuracy in Watershed Simulations. Transactions of the ASABE, 50, 885-900. https://doi.org/10.13031/2013.23153

[34] Santhi, C., Arnold, J., Williams, J.R., Dugas, W.A., Srinivasan, R. and Hauck, L.M. (2001) Validation of the SWAT Model on a Large River Basin with Point and Nonpoint Sources. Journal of the American Water Resources Association, 37, 1169-1188. https://doi.org/10.1111/j.1752-1688.2001.tb03630.x 